University of Nebraska - Lincoln

DigitalCommons@University of Nebraska - Lincoln

Faculty Publications in Educational

Administration

Educational Administration, Department of

Winter 1-24-2022

\title{
Beyond the School Walls: Collective Impact in Micropolitan School-Community Partnerships
}

\author{
Sarah Zuckerman \\ University of Nebraska-Lincoln, szuckerman2@unl.edu
}

Follow this and additional works at: https://digitalcommons.unl.edu/cehsedadfacpub

Part of the Educational Administration and Supervision Commons

Zuckerman, Sarah, "Beyond the School Walls: Collective Impact in Micropolitan School-Community Partnerships" (2022). Faculty Publications in Educational Administration. 151.

https://digitalcommons.unl.edu/cehsedadfacpub/151

This Article is brought to you for free and open access by the Educational Administration, Department of at DigitalCommons@University of Nebraska - Lincoln. It has been accepted for inclusion in Faculty Publications in Educational Administration by an authorized administrator of DigitalCommons@University of Nebraska - Lincoln. 


\title{
Beyond the School Walls: Collective Impact in Micropolitan School-Community Partnerships
}

\author{
Sarah J. Zuckerman \\ University of Nebraska-Lincoln \\ 132 TEAC, Lincoln NE 68588; szuckerman2@unl.edu \\ ORCID \\ Sarah J. Zuckerman http://orcid.org/oooo-ooo2-3330-6431
}

\begin{abstract}
Research suggests that the time students spend outside of school, as well as the communities in which they spend it, impact educational outcomes. Inequitable educational outcomes are the result of complex, interdependent problems in the public and private sector, suggesting the need for approaches that bring together schools with other organizations to address problems in the ecological and developmental systems of family, school, out-of-school programs, and communities. Collective impact has gained prominence as a strategy for such cross-sector partnerships. This qualitative study uses a comparative approach to extend knowledge of collective impact into rural and micropolitan communities using civic capacity as a framework. It identifies limitations in mobilization of members and issue framing which suggest a need to reconceptualize collective impact as a political arrangement, rather than an organizational one. The findings suggest the need to engage in community organizing activities to build political capital by confronting social isolation and exclusion among groups, examining power and privilege among community members and developing critical place-based leadership for intergenerational capacity building.
\end{abstract}

Published in Peabody Journal of Education (2022)

doi:10.1080/0161956X.2022.2026724

Copyright (C) 2022 Taylor \& Francis Group, LLC. Used by permission. 
Rearch suggests that the time students spend outside of school, 1 as well as the communities in which they spend it, impact their academic success (Reardon et al., 2019). School-community partnerships, unlike most educational reforms, seek to address child development beyond the school walls (Leonard, 2011). In recent years, school-community partnerships using collective impact (CI), have been identified as a potential systems-level intervention for the intractable, multidimensional challenges faced by children (Riehl et al., 2019). Unlike previous school-community partnership models (e.g., Dryfoos, 1995), CI operates at a municipal or regional level by bringing together educational, social service, business, and civic sectors around shared goals (Henig et al., 2015). CI efforts seek to reorganize decision-making, reduce fragmentation, and foster coherence among educational and youth-serving organizations (Riehl et al., 2019). As such, CI can be seen as an ecological approach to improving outcomes (Tilhou et al., 2020). Henig et al. (2015) identify three important dimensions for understanding CI in education: service provision for disadvantaged youth; organizational partnering activities; and the politics of coalition formation, including how members work across ideological, racial, and class lines. This descriptive cross-case study (Yin, 2014) focuses on the third aspect by addressing two research questions: (1) How do collective impact efforts form coalitions in micropolitan communities and (2) how do members frame problems and goals?

This study responds to calls for a greater understanding of the implementation of CI in rural contexts (Klaus \& Weaver, 2019). While proponents suggest that $\mathrm{CI}$ is a flexible approach that can be tailored to diverse communities (Walzer et al., 2016), limited research exists on these partnerships in rural and micropolitan ${ }^{1}$ communities. This study also contributes to knowledge of how CI efforts develop. Henig et al. (2015) state if "partial, fragile, weak, and ephemeral efforts are the norm," (p. 5) focusing only on those that have met definitional criteria misses an opportunity to understand why many CI efforts have yet to fully ramp up and what might be done to help them achieve systems-level change for student and community outcomes.

1 As defined by the U.S. Census Bureau, rural communities are those with fewer than 2,500 residents outside of an urbanized area and are home to 46 million Americans. Micropolitan areas consist of an urban cluster of less than 50,000, but at least 10,000 and are home to 27 million (U.S. Census, 2019; Wilson et al., 2012). 


\section{Review of the literature}

\section{Relation of collective impact to previous partnership efforts}

School-community partnerships are "intentional efforts to create and sustain relationships among a K-12 school or school district and a variety of both formal and informal organizations and institutions in the community" (Melaville, 1998, p. 6). Such efforts have a long history in the U.S. going back to the nineteenth century settlement houses. The importance of partnering activities to support child development was heightened by the mid-twentieth century federal efforts to alleviate poverty that resulted in a variety of categorical programs, creating a need to coordinate service provision locally. This need was met by organizations outside of local government, resulting in parallel political structures that failed to achieve program goals (Henig et al., 2015). Following the rise in full- service and wraparound models in the early 2000 (e.g., Dryfoos), more ambitious partnership models aimed at overcoming the fragmented nature of service provision have emerged, including Promise Neighborhoods and Strive models (Henig et al., 2015). These models differ from previous partnership efforts in scope, bringing together business and civic sector stakeholders with educational and service providers to create comprehensive supports.

\section{The five conditions of collective impact}

The original CI model defined by Kania and Kramer (2011) describes five conditions of successful cross- sector collaboration: a common agenda with shared goals and strategies; shared measures; mutually reinforcing activities that eliminate redundancy and align to the common agenda; constant communication; and a backbone organization. The Strive Partnership in Cincinnati was identified as an early exemplar of CI with the broad mobilization of private and public sector members; development of a "roadmap" or common agenda for student success; and the use of common metrics, including school readiness, 3rd grade literacy scores, 8th grade math scores, high school graduation, postsecondary completion, and career readiness. This work is supported by data informed decision-making, ongoing communication, and by a backbone organization with dedicated staff to support collaboration (Kania \& Kramer, 2011). 
Over the past decade, CI has been embraced as a strategy to address the intractable problem of improving educational outcomes, with 182 CI efforts identified in the 100 largest U.S. cities (Boyer et al., 2020; Henig et al., 2016). Despite the expansion of CI in education, empirical research remains slim. The initial CI literature (e.g., Kania \& Kramer, 2011) has been criticized as normative and prescriptive (Henig et al., 2015). More recent literature has been described as "gray," as it has been authored by those leading or evaluating CI efforts (Boyer et al., 2020; Henig et al., 2015). Such literature paints an overly rosy picture of an approach that shows limited evidence of systems-level changes (Ennis \& Tofa, 2020).

\section{Inadequate attention to mobilization and issue framing}

The literature suggests the limited evidence of systems-level change may be due to inadequate attention to participant mobilization and issue framing, including problem definition and generation of potential solutions. The focus of CI on recruiting CEO level leaders (Riehl et al., 2019) tends to result in mobilization of white, middle-class professionals and elites who lack firsthand knowledge of social problems (LeChasseur, 2016). Ennis and Tofa (2020) suggest that the absence of community voice is due to contemporary top-down community development practice and that "a lack of community voice curtails much needed challenges to the entrenched vested interests of the status quo" (p. 44).

Top-down mobilization in turn impacts how problems and potential solutions are framed as professional knowledge and knowing are privileged as part of the dominant culture (Biddle et al., 2018; LeChasseur, 2016). While framing can disrupt power structures, it can also be used to limit change. The frames of abstract liberalism, which prioritize individualism and choice, can both explain and hide structural inequities (LeChasseur, 2016). As a result, CI efforts frequently focus on improving community-level outcomes without attending to the differences between groups and using indicators based on individual behavior (e.g., reduction in drug use) while overlooking the need for systems change (e.g., criminal justice reforms), thus perpetuating inequities (LeChasseur, 2016). As a result, CI efforts may not address the need for relationship development and identity formation that support rural community well-being (Casto et al., 2016). 


\section{Engagement of youth in social movement building}

One approach to building relationships and shared identity for rural community development is the engagement of youth. This strategy can challenge traditional frames and power structures, as well as contribute to development of intergenerational relationships for community development (LeChasseur, 2016; Zuckerman \& McAtee, 2018). The engagement of youth in CI aligns with the collective impact 3.0 model, which calls for a paradigm shift from managerial approaches to social movement building (Weaver \& Cabaj, 2019). In CI 3.0, each of the five CI conditions is transformed: common agenda is replaced by shared aspirations based on community values; shared measurement is reframed as strategic learning; mutually reinforcing activities becomes high leverage opportunities for change; continuous communication is envisioned as authentic community engagement built through relationships and trust to broaden understandings of problems; and lastly, reimagining the backbone organization as a container for change by providing facilitation and structures for mobilizing members, leading sensemaking, building relationships, and navigating the tensions of change (Weaver \& Cabaj, 2019).

\section{Collective impact in smaller communities}

Henig et al., (2016) suggest that partnerships may be easier to initiate in smaller communities due to more homogenous populations and increased face-to-face interactions. Indeed, rural communities may offer strengths for school-community partnership work, such as strong social networks, shared identities, and a close relationship between schools and communities (Tieken, 2014). However, they also present challenges, including limited resources (Brown et al., 2004) and economic, social, and political inequities based on race, class, and geography that create social isolation and exclusion that negatively impact community cohesion (Sherman, 2021). Limited mobilization of those experiencing social problems, inattention to power dynamics, and abstract liberal issue framing have been suggested as reasons CI efforts may not reach their potential (LeChasseur, 2016). Therefore, how rural CI efforts bring people together and how they frame needs is important for understanding their potential for social innovation in nonmetropolitan contexts (Zuckerman, 2020b). 


\section{Conceptual framework}

\section{Civic capacity}

The episodic nature of collaborative efforts to improve educational outcomes reflects the political reality that individuals and organizations hold values and interests that do not easily align (Henig et al., 2015). CI can be conceptualized as a container for civic capacity development through its mobilization of cross-sector coalitions for collaborative decision-making to address a common problem with roots in multiple parts of the developmental ecology (Riehl et al., 2019; Stone et al., 2001; Zuckerman, 2016a). Viewed through the lens of political science, mobilization of members and issue framing that occurs in these new civic arenas are important areas of analysis in CI efforts (Henig et al., 2015; LeChasseur, 2016).

\section{Mobilization}

Kania and Kramer (2011) wrote that CI is, "the long-term commitments of a group of important actors from different sectors to a common agenda to solving a specific social problem" (p. 39). This definition aligns with the political science concept of civic capacity. Civic capacity is the ability of a community to make substantial and sustained investment in the human capital development of young people (Stone et al., 2001). Civic capacity requires a broad mobilization of sectors to pursue change and a commitment over time to actively work on a problem (Stone et al., 2001). Embedding a reform initiative in a broad coalition creates momentum that can withstand changes in leadership (Briggs, 2008). Riehl et al. (2019) suggest broad coalition building is a key benefit of $\mathrm{CI}$ that can reduce policy churn in education reform.

\section{Issue framing}

However, mobilization alone is insufficient to generate civic capacity capable of change. Shared issue framing, or common understandings of problems and potential solutions, is necessary to drive collective action (Stone et al., 2001). Within the new civic arenas created by CI, members engage in sensemaking processes (e.g., dialogue, strategic 
goal setting, and negotiation of conflict) to develop collective action issue frames (Stone et al., 2001; Zuckerman, 2019). Collective action issue frames differ from everyday interpretive frames in that their purpose is to mobilize and activate people to a cause and to neutralize opponents' messages (Snow et al., 2018). Therefore, collective action issue frames must be broad enough to attract more members and specific enough to support change (Ansell et al., 2009).

Research on coalitions for school reforms and school-community partnerships suggest that the groups and interests represented in the coalition matter for how local policy agendas are shaped through processes of collective action issue framing (Benford \& Snow, 2000; Shipps, 2003). However, the reciprocal relationship between mobilization and issue framing (Zuckerman, 2016a) can create tensions between grassroots community organizations and those who hold power (Briggs, 2008). In the CI literature, this tension has been identified as reducing potential for systems-change (Ennis \& Tofa, 2020; LeChasseur, 2016).

\section{Rural contexts}

The rural education literature highlights a need to attend to power and privilege across ethnic, racial, and class stratification, heightened by moral judgements of poverty that shape the ways rural schools and communities invest in children (Biddle et al., 2018; McHenry-Sorber, 2014; Sherman, 2021). Social stratification and moral judgment create barriers to participation in the local economic, political, and social networks that create reciprocal processes within civil society (Sherman, 2021). Social stratification also contributes to differences in identities, values, and understandings of the problems faced by rural communities (Biddle et al., 2018; McHenry-Sorber, 2014). Competing narratives and attempts to consolidate power among different community factions must be overcome to create partnerships capable of change (McHenry-Sorber, 2014), suggesting specific challenges to CI development in rural places.

Based on this conceptualization of CI as a container for civic capacity development, two areas require deeper investigation: (1) mobilization, or how members of the public and private sectors are brought together into these new civic arenas; (2) how issues are framed or understood by members, including the goals and strategies to meet them. 


\section{Method}

This study utilized secondary data analysis (Thorne, 2013) of two CI case studies conducted by the author. Comparing two similar case studies in a secondary analysis provides cross-validation of findings and allows exploration of themes previously identified by placing multiple data sets in conversation (Irwin, 2013; Thorne, 2013). Earlier findings suggested a need to further examine social networks as both a contributing and inhibiting factor in the ability of rural CI to promote social innovation necessary for community-level change (Zuckerman, 2016b, 2020a).

\section{Cases}

While each case (Table 1) was identified independently, both were purposefully sampled to address a gap in the $\mathrm{CI}$ literature. These cases were deemed comparable due to similarities in their goals of improving outcomes for children across the developmental continuum from early childhood through transitions to adulthood and their mobilization of members of educational, social service, health, and youth-serving organizations. Descriptions of each case follow.

Table 1 Site characteristics 2019 estimates.

\begin{tabular}{lcc} 
& $\begin{array}{c}\text { Grand Isle } \\
\text { Network }\end{array}$ & $\begin{array}{c}\text { Northeast Prairie } \\
\text { Coalition }\end{array}$ \\
\hline County population & 45,000 & 35,000 \\
Micropolitan center population & 11,000 & 24,500 \\
Percent White & $90 \%$ & $80 \%$ \\
Percent African American/Black & $<1 \%$ & $<5 \%$ \\
Percent Hispanic/Latino & $<5 \%$ & $>15 \%$ \\
Percentage Native American & $<5 \%$ & $<5 \%$ \\
Percentage Asian & $<1 \%$ & $<5 \%$ \\
Population density per square mile & 20 & 60 \\
Nonmetro county type & Recreation & Nonspecialized \\
Per capita income (2018 dollars) & $\$ 28,600$ & $\$ 27,500$ \\
Poverty rate & $10 \%$ & $10 \%$ \\
\hline
\end{tabular}

Numbers have been rounded to prevent deductive disclosure.

a. Updated from nonspecialized in 2015 . 


\section{The Grand Isle network}

The Grand Isle Network (GN) was selected due to its affiliation with Strive, identified as an early exemplar of CI (Kania \& Kramer, 2011). GN is centered in a micropolitan employment, retail, and service "hub" that serves 30 rural communities and a Native American reservation in a heavily forested area of the Upper Midwest. Historically, logging, mining, and farming formed the base of the local economy. Participants reported these jobs have been replaced by low wage service and seasonal tourism jobs. Initially, GN members came together around academic achievement but shifted their focus to positive youth development. Partners included members of school districts, early childhood programs, the local community college, businesses, government agencies, nonprofit, and faith-based organizations. A local private foundation (the Foundation) served as the backbone organization.

At the time of data collection, GN had publicly launched a baseline data report from a youth survey and was organizing for action with the engagement of action-planning teams in several school districts. Participants reported this decentralized approach was necessary due to the challenges in collaborating across communities. Although school-based groups were engaged in action planning, participants described schools as "immovable objects," resulting in a focus on outof-school and early childhood programs (Zuckerman, 2020b). In late 2018, GN released a second survey report. However, website activity suggests GN has been inactive since early 2019.

\section{Northeast Prairie coalition}

The Northeast Prairie Coalition (NPC) was selected due to its explicit use of the CI model. NPC is located in and primarily serves a micropolitan "hub" community in a rural county described as a crossroads of feed corn and cattle production in a Great Plains state. The prevalence of the retail industry is evidenced by big box stores and fastfood outlets. Manufacturing and health care provide some higher wage employment. Participants described economic residential segregation, which was evident as mobile homes and low-income rental properties gave way to increasingly larger homes rising toward a man-made lake. 
NCP included four working groups: early childhood, basic needs, prevention, and transitions to adulthood. Partners included members of local government agencies, a community health center, early childhood providers, nonprofits and faith-based organizations, and the local school district. NCP was supported by a nonprofit organization (GPCF) located in an urban area that served as the "backbone to the backbone" for CI efforts in the state through grants and a network of conveners. At the time of data collection, the local United Way served as the fiscal agent and the steering committee was in the process of applying for $501 \mathrm{C}$ (3) nonprofit status. Efforts by NPC largely focused outside school, including after-school activities in partnership with the juvenile justice department, a youth summit, and early childhood education. In the summer of 2019, NPC experienced turnover of the convener and has since had two conveners. Despite this turnover, and turnover among members, NPC remains an active coalition.

\section{Data collection}

Each data set was developed through significant engagement in the field, with over 130 hours spent at each site. Fieldwork in Grand Isle occurred during two week-long site visits between November 2014 and June 2015. Table 2 lists participants by sector. At GN, 40 individuals participated in 28 interviews and six focus groups, four of which were conducted by the group's developmental evaluator. ${ }^{2}$ Fieldwork in Northeast Prairie consisted of monthly visits from September 2017 to June 2018. At NPC, 18 members were interviewed, and five additional members took part in a focus group held by their developmental evaluator. In both cases, the conveners (individuals who serve as neutral organizers) facilitated the inclusion of the researcher in these focus groups to reduce the burden on members. Drawing from a literature review on organizational partnerships and civic capacity (see, Zuckerman, 2016a), interview protocols were designed to elicit participants' perceptions of the community, opportunities, and aspirations for youth; factors that contributed to mobilization of members and commitment to collaboration; framing of problems and potential solutions; and strategies to meet goals.

2 Developmental evaluation is a formative approach to evaluation that provides additional information for learning to support collective change (Walzer et al., 2016). 
Table 2 Interview and focus group participants.

\begin{tabular}{lcc} 
& $\begin{array}{c}\text { Grand Isle } \\
\text { Network }\end{array}$ & $\begin{array}{c}\text { Northeast Prairie } \\
\text { Coalition }\end{array}$ \\
\hline K-12 Administrators & 5 & 2 \\
K-12 Teachers/staff & 7 & 2 \\
Government agency & 4 & 4 \\
Nonprofit & 4 & 7 \\
Business & 3 & 1 \\
Health care & 0 & 3 \\
Early childhood & 1 & 2 \\
Postsecondary education & 2 & 0 \\
Conveners and backbone staff & 8 & 4 \\
Other & 6 & 2 \\
Total & 40 & 23 \\
\hline
\end{tabular}

\section{Data analysis}

Initially, each set of data was coded separately using a combination of deductive and abductive approaches. Abductive approaches examine the ways in which the data do not fit preexisting theory (Saldaña, 2014). This hybrid approach allowed for an examination of key factors associated with organizational partnerships and civic capacity while remaining open to contextual factors. A priori coding was based on an extensive literature review (Yin, 2016) of organizational partnerships, CI, and civic capacity (see, Zuckerman, 2016a). These codes included the parent code of "mobilization" identified as a key element across the literature. Within mobilization, child codes included "identifying participants," for strategies used to identify the right stakeholders for the right roles (Lawson, 2004) from the local organizational landscape aligned to the goals, and scope of the partnership (McGrath et al., 2005). Child codes also included "social capital," which included "closed networks," "open networks," "strong ties," "weak ties" and "trust" (Miller et al., 2017). From abductive coding, "self-interest" and "interdependency" were added from descriptions of why members joined.

The literature review also identified issue framing as a key component of partnerships. In CI, issue framing is expressed as a common agenda. Parent codes included "issue framing" and "goals." Child codes were derived from the data, identifying how members described local 
problems (Benford \& Snow, 2000) and how they described partnership goals. Codes derived from the data also included "framing activities," or the various strategies and processes used to generate shared understandings of problems and goals (Benford \& Snow, 2000).

Across cases, this deductive and abductive analytic strategy identified areas for comparison to cross-validate and extend earlier findings in the areas of mobilization and issue framing. Secondary analysis began with summary reports and manuscripts produced from the initial studies (Zuckerman, 2020a, 2020b, 2019, 2016b; Zuckerman \& McAtee, 2018). Following the identification of key themes, analysis returned to coded data to engage in comparative analysis.

\section{Findings}

The findings presented focus on the two areas of CI that the literature review and conceptual framework identified as foundational for such partnerships to deliver on their promise of systems-level change across the developmental ecology: (1) what types of members were mobilized and factors that contributed to mobilization and (2) how members frame local issues?

\section{Mobilization}

While both CI efforts solicited community members' input through surveys and public meetings, the mobilization pattern of those engaged in steering committees and working groups followed that identified in previous research (Ennis \& Tofa, 2020; LeChasseur, 2016), except for the engagement of youth. In both CI efforts, participants reported that close knit social networks and shared values facilitated mobilization of members, yet these factors appeared to inhibit mobilization of those experiencing educational and other social problems and those in power.

\section{Mobilizing the middle}

Members of both CI efforts reported limited mobilization of elites and low-income community members. Members of both groups 
described challenges in bringing business leaders and elected officials to the table. At NPC, members reported local businesses and national chains may make donations but are not engaged in decisionmaking. One member shared: "If you want to get business leaders involved, you want to get chamber involved, city politicians involved ... that's almost like doing a political fundraiser." She continued, stating the effort necessary to bring community elites to the table "is beyond the scope of what any of us in the coalition are . . not our skill set ... you need somebody whose skill set is fundraising and non-profits and pulling in members. And, that's a, that's kind of a big city function." At GN, members also reported governmental leaders, such as the city administrator, were missing, with one stating, "Nobody's pulling it together," suggesting a need for intentional efforts to mobilize these individuals.

Similarly, members of both CI efforts identified the need to mobilize low-income community members. As one member of GN put it, "If you look around the table you have a lot of folks who are like us, who get paid to be there." A school administrator at GN stated engaging parents who are not typically involved in education required intentional strategies as "It's not going to happen by invitation or natural interactions." To bridge class divides, a member of NPC spoke of a desire to create spaces where more natural interactions could happen, including a community center on Main St where, "different socioeconomic groups could mix" with patrons able to "buy an extra cup of coffee on reserve for someone who might not have." However, he reported that middle class community members were not open to sharing spaces "where someone overtly by looking at them you can see maybe they are having difficulties." This suggested a broader resistance to relationship building across class lines that may have limited mobilization.

\section{Close social ties}

While there appeared to be limited social ties across class lines at both sites, participants reported the mobilization of members was supported by tight knit social networks facilitated by the small size of the communities. As a member of NPC put it, "It is easier to interact, easier to run into [people] . . . so I think that makes it easier to get 
started." At GN, the convener spoke of the multiple overlapping relationships members have as residents in a small community. In both cases, CI efforts built from previous collaborations. At GN, members reported collaboration in $\mathrm{K}-12$ went back 20 years, while a member of NPC reported members of the early childhood committee were "tried and true" after eight years of working together.

The closed nature of these relationships presented barriers to mobilization, including distrust between groups. This was most evident at GN, where members reported limited mobilization of Native American residents. One member stated, "Unfortunately, they [Native Americans] have not seen themselves in the work." The lone Native American GN member reported many white residents held negative stereotypes, contributing to ongoing distrust:

They don't realize that not all Natives are on welfare, not all Natives are alcoholics. And some of the reason that they are those things is because of the historical trauma. I think that really plays a huge part in how things go on here.

While the Foundation engaged in efforts to heal the enduring harm of white colonization, they remained outside of the Grand Isle Network.

\section{Shared values}

Like relationships, shared values contributed to mobilizing the middle. Participants at both sites reported new members were "vetted" for shared values. At GN, shared values included the importance of youth to community development. At NPC, shared values were described as "a desire to make the community better" and a commitment to children. Yet the use of certain values as a gatekeeper may have inhibited broader coalition formation. In particular, at GN, members reported some community members held different values related to out-ofschool time with one member stating middle class parents valued the arts and music and low-income parents valued hunting and fishing. These comments implied a judgment of those who held different values for out-of-school time. 


\section{Boundary spanners}

Despite challenges in mobilization created by social boundaries, two members of NPC played unique roles as boundary spanners. As the bilingual children of Mexican immigrants, the convener and one of the members of the early childhood work group were able to bring people together in unique ways. They reported that despite a lack of interest in an English-only parenting course sponsored by NPC, they were able to bring new arrival Latino families together with white families in a bilingual version. The early childhood member described planning a celebration in honor of Mexico's Mother's Day, "We're going to do a special meal ... a and tres leches cake. A lot of those moms don't get celebrated. Since [the convener] and I are both Mexican, we're going to celebrate ourselves too." This statement suggested the importance of not only shared language, but also of shared identity in crossing social boundaries to engage immigrant residents that some described as experiencing social isolation and exclusion.

\section{Youth engagement}

While both efforts struggled with mobilization of elites and low-income community members, they both actively engaged youth. At GN, efforts included invitations and transportation for youths to attend a public meeting where they engaged in data analysis with adults. GN members set the tone for youth participation with comments from the podium such as: "We have a lot to learn from you [youth] and our conversations will be richer because of you." Following this meeting, youth were mobilized for district-level action planning. In two districts, participants reported efforts to ensure the students mobilized included "kids that might have a different perception of what it means to be connected because they're not involved in sports and stuff" and "kids from a broad section who aren't used to having their voice actually being heard." In another district, members described the adults forming a circle around students to ensure everyone knew they were central to the action planning.

At NPC, engagement of young people appeared somewhat more limited to a youth leadership effort and a youth summit. One member described the youth leadership effort as preparing a small number 
of youths to engage with the legislature and in civic projects of their choice. Participants reported a goal for the youth summit was to build relationships across racial and socioeconomic groups that reportedly did not develop due to residential segregation and zoned elementary schools. Like GN, a school administrator spoke of recruiting youth to plan the summit who were not the typical "good kids" but who were influential with their peers.

\section{Collective action issue framing}

Collective action issue framing in both CI efforts reportedly began with informal conversations among community and educational leaders with shared concerns about educational outcomes. As they developed, both CI efforts created multiple venues for members and the wider public to engage in face- to-face dialogue to identify community needs and develop goals. Issue framing was more coherent among members of GN, with a codified goal statement on student success developed over years of intentionally facilitated dialogue. Members of NPC identified a range of goals under the overarching aim of preventing involvement in the child welfare system.

\section{From student success to vibrant community}

At GN, the initial name of the group featured the phrase "student success." Over time, the framing used by members evolved through sensemaking processes (see, Zuckerman, 2019) in new civic arenas of steering committee meetings. At GN, the convener reported initial conversations focused on the No Child Left Behind "rhetoric of failing schools," but a shared learning experience shifted perspectives to a broader framing to "integrate family supports and community into the schools." Following this shift, GN developed a set of shared goals codified in a "road map document" that members referred to frequently and was visible in several interview locations. This roadmap consisted of a series of statements about student outcomes from school readiness to grade-level learning to postsecondary enrollment and completion, as well as a series of statements about what all students would have access to in the community. 
However, these frames raised questions among members and conflict with the larger community. GN members were careful to state they defined postsecondary education as "any education after high school." This appeared to be a strategy to make their goal of increasing college completion more palatable to community members who feared that young people who went away to college would not return to the community. Despite a reported lack of broad commitment to a postsecondary agenda, a member of the backbone organization stated, "We're going to change the climate on that."

In addition to navigating this contentious goal, members reported unease with the framing of student success. In a focus group, members discussed a series of youth suicides and attempts, questioning how "student success" was defined. One relayed her personal experience, "I had somebody close to me whose child committed suicide and that child was a $4.0+$, was the top of his class, was a three-season letter winner, had his own business at 16, and killed himself." She continued, “There's no drugs, there's no girl issues, there's no nothing that they can pinpoint. And for all intents and purposes, he's success. But we missed the boat somewhere."

Rather than emphasizing traditional notions of success, such as academics and sports, members reported a shift in thinking about how to create connections between youth and community and defining success at the community level, including job creation, the development of intergenerational relationships, and civic responsibility. One member described a successful community as "vibrant ... . willing to make changes, to adjust with what's needed by the people that live in that community." This led to rebranding efforts and a more inclusive name.

\section{Prevention and framing the impact of poverty}

Members of NPC identified a broad range of problems and goals related to an overarching aim of preventing involvement in the child welfare system. These included reducing the impacts of poverty, streamlining service provision, and building social capital. Across these frames, abstract liberalism focused on individuals rather than systems. For example, most members described needs related to poverty using deficit frames, such as this statement: 
We know that poverty puts these children at a disadvantage. Their outcomes and success in life are, are not gonna be as great as what it could be if they came from a middle class or a wealthy family. They lack those exposures, those experiences, even just words in, in interactions with their parents.

NPC members tended to talk about the "working poor." For example, one stated "You can have a full- time job or even two full time jobs and four children and still fall in poverty level. And so, poverty doesn't mean you are lazy or you're not working, or you're not trying." This framing appears to convey a positive moralization of those who work but do not earn a living wage; yet at the same time, it casts an unspoken judgment on the unemployed. Although less prevalent, members placed the blame for poverty on limited opportunities for those without skills. One member stated, "A single mother with children ... if there's not a skill set, or training there, it's pretty much service industry. Fast food, those kinds of positions where it is very tough to support a family." Like framing in previous CI efforts, these statements focus on individual, rather than systemic, causes of poverty. Across data collection, only one member identified employers as responsible for low wages, exclaiming, "Why do we let them get away with this!?”

In terms of meeting the needs of such families, members described a desire to reduce the "the fragmentation of our services." Members reported a goal to increase coordination and communication among providers to reduce redundancy, to connect people to providers, and as one member put it "to hopefully eliminate some of the round-robin that families do with seeking assistance" by helping stabilize families. Yet, in an offhand statement before a meeting, the convener mentioned that they were still seeing the same families seeking help, suggesting either the programs offered, or a programmatic approach in general, was insufficient to meet needs.

The convener reported pushback from the community in attempts to better serve unmet needs. She gave the example of efforts to locate a childcare facility near the high school, stating "We've had [moral judgment] with supporting pregnant teens and setting things up so they can spend part of their day with the baby and people saying, 'Well, you're just rewarding them, then, for having babies.'” At the 
same time, she reported the school board was "not ready for sex ed." Another member reported the community did not see the need to expand services like mental health care, summing up the attitude as "Well why do you need that because we grew up and we didn't have that." These comments suggest that while those mobilized shared commitments to "all of our kids" the wider public did not, limiting the breadth of the CI effort.

Challenges in reaching broad mobilization through collective action frames appeared related to the isolation and exclusion of certain groups. One member of NPC stated a need to "help grow a good, healthy social network for those families." Given pushback against creating free public spaces by adults, several members spoke of the planned youth forum as a way to get ahead of these attitudes. Describing his own experiences in the district schools, a recent college graduate and the youngest NPC member, reported that residential segregation combined with zoned elementary schools and tracking in secondary schools contributed to insular social groups. He described the goal of the youth forum as bringing "all of these kids together because ... the disadvantaged kids have something to learn from the wealthier kids and the wealthier kids have something to learn from disadvantaged kids ... And hopefully kind of bridge those gaps.”

\section{Conclusion}

Over the last decade, collective impact has spread across the U.S. as a strategy to create new social and organizational structures in order to address the complexities of the currently fragmented developmental ecosystem that contributes to inequities in educational outcomes (Boyer et al., 2020). However, partial and ephemeral expressions of CI remain the norm (Henig et al., 2015). The findings of this study suggest that $\mathrm{CI}$ efforts in micropolitan communities can create new civic arenas for face-to-face dialogue between individuals across ecological settings (Tilhou et al., 2020). However, through the lens of civic capacity, the mobilization patterns and issue framing of each CI effort appears to have limited their ability to engage in systems-level change. This appeared to be due to the reciprocal relationship between narrow mobilization of members and issue frames that did not resonate widely with the greater community. 
The main contribution of this study is the recognition that CI efforts in smaller communities face many of the same challenges as those in urban areas. Although some suggest that collaborative partnerships may be easier to develop in small communities (Henig et al., 2016), my findings suggest that CI efforts in micropolitan communities struggle with narrow mobilization of members. This narrow mobilization limited who had a voice in crafting the issue frames used by these efforts to guide their actions and recruit new members. Whether they were addressing postsecondary completion or the issue of teen parenthood, each CI effort struggled with crafting frames that were broadly compelling, credible, and morally acceptable to the community at large (Zuckerman, 2019, 202ob). Without their voices and self-interest represented in the common agenda, both low-income and community elites may to be difficult to engage (Zuckerman, 2016a). These findings mirror those of Riehl et al. (2019), which suggest mobilizing grassroots groups and elites is not easy or straightforward.

Drawing from research in urban and rural partnerships, this study offers several recommendations for $\mathrm{CI}$ that can create civic capacity in smaller communities. First, the findings illustrate that smaller communities cannot be assumed to be homogenous. While close social ties facilitated mobilization of certain members, they also excluded others. Issues of class and race, along with value systems and identities, must be addressed to create opportunities for community members experiencing social problems to be part of the solution (Biddle et al., 2018; McHenry-Sorber \& Budge, 2018). In smaller communities, examinations of power need to attend to how moral capital is used to limit access to human and social capital by labeling those who are worthy of investment and by stigmatizing service access (Sherman, 2021). Sherman (2021) suggests without strategies to call attention to all three forms of capital, problem identification may continue to focus on individuals and obscure systematic inequities.

The second implication is the acknowledgement of CI as a political endeavor. The findings suggest each CI effort created new civic spaces, yet they had not generated the political capital necessary to support a community- or regional-level developmental ecology encompassing schools, youth serving organizations, and others that directly or indirectly impact child development. Political capital is defined as the ability of people to engage in collective action for the well-being of 
the community (Flora et al., 2018). This vision of political capital requires moving beyond traditional adversarial politics to develop collaborative governance of schools and other public agencies (Ansell \& Gash, 2008). Meaningful collaboration requires a strong foundation of trust, open communication, shared power, shared understandings, leadership, and a recognition of interdependency (Ansell \& Gash, 2008). Previous research (e.g., McHenry-Sorber, 2014) suggests these elements cannot be taken for granted in smaller communities. Therefore, they must be developed through strategies such as community organizing to identify shared problems, mobilize community members, and build collective power (Christens \& Inzeo, 2015). Developing power through new and altered relationships between microsystems contributes to macro-level connections across the developmental ecology (Christens et al., 2014). Significant resources must be put behind this work, particularly for regional efforts in rural areas, such as that served by GN, where community members live miles away from schools and one another.

Lastly, while this study did not directly address leadership, the boundary spanning role played by two bilingual members of NPC suggest leadership as an area for attention. This includes identifying leaders who share identities with those who are socially isolated and excluded. Similarly, facilitative leadership contributes to relationship building, working through conflict, empowering those whose voices are often excluded, developing collaborative processes, and creating the shared understandings necessary for broad, credible, morally acceptable collective action frames (Ansell \& Gash, 2008; Zuckerman, 2019, 2020a).

Developing critical place-based leadership (McHenry-Sorber \& Budge, 2018) for educational and community leaders holds potential to strengthen CI partnerships. Critical place-conscious leadership recognizes the interdependency of schools and their communities and works to reconnect education and human development to community well-being (McHenry-Sorber \& Sutherland, 2020). Such approaches broaden the view of educational outcomes to include relationship and identity formation (Casto et al., 2016). The goal of such efforts is to teach youth to see and critique systems that threaten collective well-being and to engage in democratic and collective action (McHenry-Sorber \& Provinzano, 2017). Intergenerational partnerships 
(Zuckerman \& McAtee, 2018) using critical place-based leadership could build from the youth engagement efforts described at both sites. Together, these approaches offer potential to move toward systemslevel change by engaging in a critical appraisal of the local developmental ecology for children while building individual and collective capacity for action.

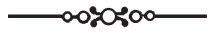

Acknowledgment I wish to acknowledge Dr Cailen O'Shea for his assistance in data collection in Northeast Prairie and LaDonna Werth and Lee Sherry of Nebraska Extension for their contributions to the Northeast Prairie study design.

Sarah J. Zuckerman, Ph.D., is an assistant professor in the Department of Educational Administration at the University of Nebraska-Lincoln. She is a former early childhood and elementary special education teacher, serving in urban and rural districts. Her research examines how educational and community leaders promote collective action to address local challenges and improve outcomes for children, with a focus on mobilization of community and organizational members; issue framing and sensemaking; and developing capacity for change.

\section{References}

Ansell, C., \& Gash, A. (2008). Collaborative governance in theory and practice. Journal of Public Administration Research and Theory, 18(4), 543-571. https:// doi.org/10.1093/jopart/mumo32

Ansell, C., Reckhow, S., \& Kelly, A. (2009). How to reform a reform coalition: Outreach, agenda expansion, and brokerage in urban school reform. Policy Studies Journal, 37(4), 717-743. https://doi. org/10.1111/j.1541-0072.2009.00332.X

Benford, R. D., \& Snow, D. A. (2000). Framing processes and social movements: An overview and assessment. Annual Review of Sociology, 26(1), 611-639. https://doi.org/10.1146/annurev.soc.26.1.611

Biddle, C., Mette, I., \& Mercado, A. (2018). Partnering with schools for community development: Power imbalances in rural community collaboratives addressing childhood adversity. Community Development, 49(2), 191-210. https://doi.org/ 10.1080/15575330.2018.1429001

Boyer, A. M., Cooper, K. R., Dougherty, S. M., Wang, R., \& Shumate, M. (2020). Predicting community adoption of collective impact in the United States: A national scan. Nonprofit and Voluntary Sector Quarterly, 0899764020964583. https://doi.org/10.1177/0899764020964583 
Briggs, X. S. (2008). Democracy as problem solving: Civic capacity in communities across the globe. The MIT Press.

Brown, D. L., Cromartie, J. B., \& Kulcsar, L. J. (2004). Micropolitan areas and the measurement of American urbanization. Population Research and Policy Review, 23(4), 399-418. https://doi. org/10.1023/B:POPU.0000040044.72272.16

Casto, H. G., McGrath, B., Sipple, J. W., \& Todd, L. (2016). "Community aware” education policy: Enhancing individual and community vitality. Education Policy Analysis Archives, 24, 1-30. https://doi.org/10.14507/epaa.24.2148

Christens, B. D., Inzeo, P. T., \& Faust, V. (2014). Channeling power across ecological systems: Social regularities in community organizing. American Journal of Community Psychology, 53(3-4), 419-431. https://doi.org/10.1007/ S10464-013-9620-4

Christens, B. D., \& Inzeo, P. T. (2015). Widening the view: Situating collective impact among frameworks for community-led change. Community Development, 46(4), 420-435. https://doi.org/10.1080/15575330.2015.1061680

Dryfoos, J. G. (1995). Full service schools: Revolution or fad? Journal of Research on Adolescence, 5(2), 147-172. https://doi.org/10.1207/s15327795jra0502_1

Ennis, G., \& Tofa, M. (2020). Collective impact: A review of the peer-reviewed research. Australian Social Work, 73(1), 32-47. https://doi.org/10.1080/03124 07X.2019.1602662

Flora, C. B., Flora, J. L., \& Gasteyer, S. P. (2018). Rural communities: Legacy and change. Routledge.

Henig, J. R., Riehl, C. J., Houston, D. M., Rebell, M. A., \& Wolff, J. R. (2016). Collective impact and the new generation of cross-sector collaborations for education: A nationwide scan. Department of Education Policy and Social Analysis, Teachers College.

Henig, J. R., Riehl, C. J., Rebell, M. A., \& Wolff, J. R. (2015). Putting collective impact in context: A review of the literature on local cross-sector collaboration to improve education. Teachers College, Columbia University, Department of Education Policy and Social Analysis. http://www.wallacefoundation.org/ knowledge-center/Documents/Putting-Collective-Impact-Into-Co811ntext.pdf

Irwin, S. (2013). Qualitative secondary data analysis: Ethics, epistemology and context. Progress in Development Studies, 13(4), 295-306. https://doi. org/10.1177/1464993413490479

Kania, J., \& Kramer, M. (2011). Collective impact. Stanford Social Innovation Review, 9(1), 36-41. https://ssir.org/articles/entry/collective_impact

Klaus, T., \& Weaver, L. (2019). Progress, challenges, and next steps in collective impact: Collective impact as disruptive illumination. In N. Walzer, and L. Weaver (Eds.), Using collective impact to bring community change. Taylor Francis.

Lawson, H. A. (2004). The logic of collaboration in education and the human services. Journal of Interprofessional Care, 18(3), 225-237. https://doi.org/10.1 o80/13561820410001731278 
LeChasseur, K. (2016). Re-examining power and privilege in collective impact. Community Development, 47(2), 225-240. https://doi.org/10.1080/15575330.2 $\underline{016.1140664}$

Leonard, J. (2011). Using Bronfenbrenner's ecological theory to understand community partnerships: A historical case study of one urban high school. Urban Education, 46(5), 987-1010. https://doi.org/10.1177/0042085911400337

McGrath, D., Donovan, R., Schaier-Peleg, B., \& Van Buskirk, W. (2005). The collaborative advantage: Lessons from $\mathrm{K}-16$ educational reform. Rowman \& Littlefield Education.

McHenry-Sorber, E., \& Budge, K. (2018). Revisiting the rural superintendency: Rethinking guiding theories for contemporary practice. Journal of Research in Rural Education, 33(3), 1-15. https://jrre.psu.edu/sites/default/

files/2019-08/33-3.pdf

McHenry-Sorber, E., \& Provinzano, K. (2017). Confronting rapid change: Exploring the practices of educational leaders in a rural boomtown. Leadership and Policy in Schools, 16(4), 602-628. https://doi.org/10.1080/15700763.2016. 1232833

McHenry-Sorber, E., \& Sutherland, D. H. (2020). Metaphors of place-conscious leadership in the multidistrict superintendency: Negotiating tensions of placeconsciousness and district-wide goal attainment. Journal of School Leadership, 30(2), 105-126. https://doi.org/10.1177/1052684619852693.

McHenry-Sorber, E. (2014). The power of competing narratives: A new interpretation of rural school-community relations. Peabody Journal of Education, 89(5), 580-592. https://doi.org/10.1080/0161956X.2014.956520

Melaville, A. (1998). Learning together: The developing field of school-community initiatives. Institute for Educational Leadership. https://files.eric.ed.gov/ fulltext/ED427105.pdf

Miller, P., Scanlan, M. K., \& Phillippo, K. (2017). Rural cross-sector collaboration: A social frontier analysis. American Educational Research Journal, 54(1), 193S-215S. https://doi.org/10.3102/0002831216665188

Reardon, S. F., Kalogrides, D., \& Shores, K. (2019). The geography of the racial/ ethnic test score gaps. American Journal of Sociology, 124(4), 1164-1221. https://doi.org/10.1086/700678

Riehl, C. J., Henig, J. R., Wolff, J. R., \& Rebell, M. A. (2019). Building impact: A closer look at local cross-sector collaborations for education. Teachers College, Columbia University. Department of Education Policy and Social Analysis.

Saldaña, J. (2014). Thinking qualitatively: Methods of mind. Sage Publications.

Sherman, J. (2021). Dividing paradise: Rural inequality and the diminishing American dream. University of California Press.

Shipps, D. (2003). Pulling together: Civic capacity and urban reform. American Education Research Journal, 40(4), 841-878. https://doi. org/10.3102/00028312040004841 
Snow, D. A., Vliegenthart, R., \& Ketelaars, P. (2018). The framing perspective on social movements: Its conceptual roots and architecture. In D. A. Snow, S. A. Soule, H. Kriesi, \& H. J. McCammon (Eds.), The Wiley Blackwell companion to social movements (pp. 392-410). Wiley Blackwell.

Stone, C. N., Henig, J. R., Jones, B. D., \& Pierannunzi, C. (2001). Building civic capacity: The politics of reforming urban schools. University Press of Kansas.

Thorne, S. (2013). Secondary qualitative data analysis. In C. T. Beck (Ed.), Routledge international handbook of qualitative nursing research (pp. 423434). Routledge.

Tieken, M. C. (2014). Why rural schools matter. UNC Press. https://doi. org/10.5149/northcarolina/9781469618487.001. 0001

Tilhou, R., Eckhoff, A., \& Rose, B. (2020). A collective impact organization for early childhood: Increasing access to quality care by uniting community sectors. Early Childhood Education Journal, 49(1), 1-13. https://doi. org/10.1007/s10643-020-01109-6

U.S. Census. (2019). Micropolitan statistical areas: A lens on small-towns. https:// www.census.gov/library/stories/2019/07/micropolitan-statistical-areas-smalltown-america.html

Walzer, N., Weaver, L., \& McGuire, C. (2016). Collective impact approaches and community development issues. Community Development, 47(2), 156-166. https://doi.org/10.1080/15575330.2015.1133686

Weaver, L., \& Cabaj, M. (2019). Collective impact 3.0: Extending the collective impact vision for community change 1 . N. Walzer \& L. Weaver (Eds.), Using Collective Impact to Bring Community Change (pp. 97-112). Taylor \& Francis.

Wilson, S. G., Plane, D. A., Mackun, P. J., Fischetti, T. R., Goworowska, J., Cohen, D., and Hatchard, G. W. (2012). Patterns of metropolitan and micropolitan population change: 2000 to 2010. Washington DC: US Department of Commerce.

Yin, R. K. (2014). Case study research: Design and methods (6th ed.). Sage.

Yin, R. K. (2016). Qualitative research from start to finish (2nd ed. ed.). Guilford Press.

Zuckerman, S. J. (2016a). Organizing for collective impact in rural cradle-tocareer-network [Doctoral Dissertation]. State University of New York at Albany. ProQuest.

Zuckerman, S. J., \& McAtee, J. R. (2018). Youth voice in a rural cradle-to-career network. Journal of Ethical Educational Leadership. Special Issue 1, 227-247. https://www.academia.edu/36304398

Zuckerman, S. J. (2016b). Mobilization and adaptation of a rural cradle-tocareer network. Educational Sciences, 6(4), 34. https://doi.org/10.3390/ educsci6040034

Zuckerman, S. J. (2019). Making sense of place: A case study of a sensemaking in a rural school-community partnership. Journal of Research in Rural Education, 35(6), 1-18. https://jrre.psu.edu/sites/default/files/2019-07/35-6_0.pdf 
Zuckerman, S. J. (2020a). "Why can't this work here?”: Social innovation and collective impact in a micropolitan community. Community Development, 52(4), 401-419. https://doi.org/10.1080/15575330.2020.1789183

Zuckerman, S. J. (2020b). The role of school leaders in a rural cradle-to-career network. Theory and Practice in Rural Education, 10(1), 73-91. https://doi. org/10.3776/tpre.2020.v10n1p73-91 